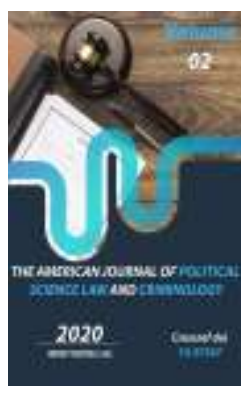

\title{
Issues Of Criminal Liability For Violation Of The Requirements Of The Law On Ecology And The Environment
}

\author{
Elbek Eshmurodov \\ Teacher Of The Department Of Private Law, Specialized Branch Of Tashkent State University \\ Of Law, Uzbekistan
}

Journal Website: http://usajournalshub.c om/index,php/tajpslc

Copyright: Original content from this work may be used under the terms of the creative commons attributes 4.0 licence.

\section{ABSTRACT}

In this article, the concept of criminal responsibility for violation of the requirements of the law on ecology and the environment, its essence, the reasons for its occurrence and commitment have been analyzed in accordance with the existing norms of law.

\section{KEYWORDS}

Ecology and environment, crime, object of crime, objective side of crime, criminal responsibility in the field of ecology and environment

\section{INTRODUCTION}

Crimes committed in the field of ecology and the environment are a complex set of crimes of non-compliance with the legislation in this area, ie they are socially dangerous acts that harm the environment and human health, aggression against social relations to ensure the rational use of natural resources, including environmental security, sustainable development of the individual, society, nation and state.

In terms of the severity of the negative consequences of crimes committed in the field of ecology and the environment as well as its demographic, environmental, social characteristics, it remains an extremely serious 
and dangerous phenomenon, posing a real threat to the security of nations. This again leads to a decrease in the average life expectancy of a person, an increase in the incidence of various diseases, death phenomena, a decline in the gene pool of the population, the emergence of ecological destruction and ecological bad zones and degradation of natural resources (soil, fish, forest, etc.).

According to Article 2 of the Criminal Code of the Republic of Uzbekistan, one of the purposes of this Code is to protect the natural environment from criminal encroachment. The Criminal Code Articles 193-204, and 2291 set out the responsibilities for crimes committed in the field of ecology and the environment. [1]

The qualitative aspect of the risk posed to society is determined by the level of social values, society and human interests that are undermined by this crime. This means that the social danger of environmental crimes is the violation of the environmental interests of society, in particular, the violation of the right of every person to have a healthy environment, damage to health, property, nature, an indication of the legalization of environmental legislation. And the degree of application of punitive measures in relation to it is determined by the scale of the crime (mass extermination of animals, the change of the active environment to the negative side, the spread of epidemics, the environmental crisis, the severe consequences of cases, etc.).

To substantiate these views, we consider it appropriate to cite some indicators of the social risk of crimes committed in the field of ecology and the environment. In particular, the increase in penalties for violations of the relevant provisions of the Criminal Code of the Republic of Uzbekistan on environmental protection is due to the upward trend of these illegal actions and their serious damage to nature and human health.

We know that the object of a crime is a social relationship protected by criminal law. Because the basis of any state structure consists of social relations. That is why the law protects these relations (Article 2 of the Criminal Code). Thus, the common object of the crime (according to Article 14 of the Criminal Code) is a social relationship that causes harm or poses a real risk of harm as a result of a criminal act (omission) protected by criminal law. Social relations in the field of environmental protection are a very complex phenomenon as an object of crime. E.N.Jevlakov believes that as a group object of crimes in the field of ecology it is necessary to recognize the complex social relations that are the basis of human life and health and are protected by criminal law for the rational use of the environment, its preservation and environmental safety. [2] A.L.Dubovik notes that the object of environmental crimes is a complex set of social relations, their legal form and material composition. The rational and ecological implementation of these relations in accordance with the norms of legislation ensures the survival of a person, the use of the environment as a basis for direct livelihood, the rational satisfaction of his social needs and his safety. [3] It can be seen that environmental relations are very complex, and therefore the identification of the object of crime in this area brings about certain difficulties. But, nevertheless, the object of crime must be correctly identified in each crime. Incorrectly identified object can lead to incorrect qualification of the crime.

The direct objects of crimes in the field of environmental protection are specified in the substance dispositions themselves. For example, the direct object of the crime of violation of norms and requirements related to 
environmental safety (Article 193 of the Criminal Code) is the social relations arising from the provision of environmental safety. That is, the legislator in the dispute indicates that the norms and regulations that provide for the preservation of environmental safety in the design, placement, construction and commissioning of industrial, energy, transport, municipal services, agro-industry, science or other objects are under the protection of the law. This means that social relations arising from the application of these norms and rules can be a direct object of crime.

The disposition of Article 194 of the Criminal Code also illustrates the details of the object of the crime. It focuses on the commitment of providing timely and accurate information about disasters caused by environmental consequences or radiation, chemical, bacterial pollution of the environment or other pollution that is dangerous to human life or health, living nature, or the state of public health. This means that crime is a social relationship that ensures that the official gives timely and accurate information about the above environmental changes. Article 195 of the Criminal Code (non-implementation of measures to eliminate the consequences of pollution of the surrounding natural environment) the ecology of a criminal object is a social relationship arising from the deactivation of contaminated areas or taking measures to restore them in a different way.

Article 196 of the Criminal Code establishes responsibility for pollution or violation of lands, pollution of water or atmospheric air. The direct object of the crime is social relations, aimed at protecting the earth, water, atmospheric air. From an objective point of view, the difference between crimes in the field of environmental protection from crimes in other areas is that as a result of crimes, damage is also caused directly to the object and other objects protected by the Criminal Code. This is the case with A.V. Naumov's textbook lists two objects as crimes. He distinguishes the direct object of two-object crimes as primary and secondary. The additional object divides itself into necessary and optional types. [4] The direct object of crimes in the field of Ecology (articles 193-196 of the Criminal Code) stands out from the main and additional necessary objects. In the dispositions of articles 194-196 of the Criminal Code, the following cases of damage as a result of the crime are indicated: mass disease of the population, extermination of animals, poultry or fish, or otherwise severe consequences.

It is also noted that a person may die as a result of the offenses specified in Part 2 of Articles 194-196 of the Criminal Code. Hence, in Articles 194-196 of the Criminal Code, a directly additional object is social relations aimed at ensuring human life and health, the survival of animals, birds or fish. As noted above, crimes in the field of environmental protection can result in damage to human life and health. But, nevertheless, these are the crimes which are included in the list of crimes in Chapter 14. This is due to the fact that the law maker considers the social relations of environmental protection as a direct object.

An additional necessary object of crimes in the field of environmental protection is the relationship that ensures human life and health, the survival of animals, poultry and fish. This object is a necessary sign for the crime structure. The object of the crime will exist only when these objects are proven. It is necessary to distinguish its subject from the object of the crime. Proper identification of the subject is of great importance, especially in crimes in the field of environmental protection. In most literature in the field of criminal law, the subject of a crime is studied separately from the object, along with the structure of the 
object. [5] They analyze the difference between the subject of the crime and the object. The subject is an optional sign, it is proved that it can be mentioned only in cases specified by law. In our opinion, a subject is different from an object. It requires separate research, but this research is "object-related, or should be investigated within". [6] That's because the analysis of the object and the subject separately does not allow to determine the relationship that is causing the damage, on the contrary, it can lead to mistakes, disqualification of the crime.

Hence, the study of the subject of crimes in the field of environmental protection stems from its connection with the object. Although the subject of the crime is very similar to the object, but they are not the same thing. The differences between them can be seen in the following cases. In objective crimes (because the subject of the crime is an optional feature, it is called subjective in crimes necessary for the composition of the crime, in cases where it is not necessary to prove). The offender affects the object during the attack on the object. As a result of the impact, the subject may change or remain unchanged. For example, in the crime of violation of environmental safety norms and requirements (Article 193 of the Criminal Code), a person commits environmental norms in the design, placement, construction and commissioning of industrial, energy, transport, communal services, agro-industry, science or other objects or in the adoption of these objects, social relations arising from the storage of requirements. The action (inaction) of an individual is the deliberate acceptance of the design, placement, construction, commissioning of objects that do not meet the environmental requirements or the fact that the object does not meet the environmental requirements. Through it, the individual is directly affecting the natural environment. As a result of the impact, some objects of the environment, including the atmosphere, water and land, may be damaged. In this case, the criminal action (inaction) of a person is not aimed at harming the natural environment, but at the relationship arising from the design, location, construction, commissioning or acceptance of an object that does not meet environmental requirements. For this reason, the subject of the crime here is the environment that is affected and harmed in the event of aggression.

It is also worth noting that all crimes in the field of Environmental Protection have a material composition, the origin of the damage is a necessary sign of it for the composition of the crime. If there are no changes that pose a risk to life in the environment, then the consequences of damage will also not arise.

The subject of crimes in the field of environmental protection has been thoroughly studied by some scientists, including Yu.I. Lyapunov. In his work, the view that "objects of nature must be in their natural state in order to be the subject of a crime" prevails, and the main focus is on the difference between the crime of looting state or public property in terms of the subject of environmental crimes. Therefore, the subject of crimes in this area should be understood as elements that perform biological or other functions of the environment and are in a natural state, or contain a certain amount of human labor, but are not separated from the natural environment due to specific labor, or grown and "mixed" in nature. [7]

"The subject of environmental crimes in the broadest sense is the natural environment," writes EN Jevlakov. According to him, all the components of the natural environment are interconnected and interrelated, forming a single ecosystem, and within specific sections of land and water bodies form a single 
community of organisms, plants and other biocenoses. [8] Indeed, the subject of environmental crimes can be the natural environment in the broadest sense. Because the objects that create the natural environment, i.e. land, water, flora and fauna, are interconnected and interact. However, these views, in our view, do not fully cover the concept of the subject of environmental crimes in the current Criminal Code (1994), because the subject of some crimes in this area is not limited to natural objects. For example, Article 194 of the Criminal Code focuses on radiation, chemical and bacterial pollution of the environment. This means that radiation, chemical and bacterial pollutants can also be the subject of environmental crimes. Therefore, in our opinion, the description given by

O.L. Dubovik on this issue fully covers the concept of the subject of crimes in the field of ecology. That is, the subject of environmental crimes are wild animals, water, forests, etc., as well as products of human activities that affect the environment and the state of its elements, such as hazardous radioactive, chemical, biological substances and waste. [9]

So, the subject of these crimes, in addition to land, water, atmospheric air, are 1) radiation, 2) chemical, 3) bacterial, 4) other pollutants that are dangerous to human life and health, living nature.

Radioactive substances are uranium, plutonium and others with natural radioactive elements. These substances can be in the form of gas, liquid or solid, packaged, finished product. The Law of the Republic of Uzbekistan "On Radiation Safety" harmonizes the rules of treatment of radioactive substances, as well as their extraction, production, re-production, processing, use, storage, maintenance, transportation, neutralization and disposal.

Radioactive waste is a material that is not intended to be used as a radioactive substance. Most of the radioactive waste is collected and stored in accordance with the relevant requirements. Only a small amount (provided that the sanitary-hygienic requirements are fully complied with) falls into the biosphere. Radionuclides, which have a long viability in water, air, and land, are harmful to the environment, which could alter some aspects of the human, flora, and fauna life cycle in the future. [10] Therefore, in order to regulate waste-related relations, the Law of the Republic of Uzbekistan "On Waste" was adopted. [11]

Thus, the subject of crimes in the field of environmental protection is the natural environment, i.e. land, water, atmospheric air, flora and fauna, radioactive, chemical, bacteriological substances and wastes. Criminal law defines liability for socially dangerous act or omission, so it is necessary to correctly determine the objective aspect of crimes in the field of environmental protection. "The objective aspect of the crime," writes V.N. Kudryavtsev, is fully described in the disposition of the Criminal Code. It is therefore not difficult to identify differences in the objective aspect of the crime. However, there are many mistakes in the application of the law. " [12]

Crimes in the field of environmental protection, like other crimes, begin with the aggression of a person through a criminal act (omission) on a relationship protected by criminal law and end with some damage to the object. The absence of external influence invalidates the origin of the crime, as any act or omission can only harm the social relations protected by criminal law. 
The proper identification of the object of the crime helps to correctly determine the objective aspect of crimes in the field of environmental protection. If social relations in the field of environmental protection and rational use of natural resources are violated as a result of crime, it is logical to assume that the use of various methods and techniques to damage these social relations leads to the objective side of the crime.

Determining whether a crime was committed as a result of an act or omission stems from a direct study of the objective aspect of each crime. The objective aspect of the crime of violation of norms and requirements related to environmental safety is the violation of norms and rules of design, placement, construction and operation of industrial, energy, transport, utilities, agro-industrial, scientific facilities; the violation of the rules by members of the state commission is characterized by the death of people, mass illness of people, changes in the environment to the extent that they adversely affect the environment, or other serious consequences.

\section{REFERENCES}

1. Criminal Code of the Republic of Uzbekistan. https://lex.uz/docs/111453

2. Jevlakov E.N. "Ecological challenges: concepts, types, problems of responsibility". Abstract of the PhD dissertation of Law. // M: 1991. p.22.

3. Dubovik O.L. "Ecological crimes: comment on Chapter 26 UK RF”. “Spark”. M:.1998. p.86.

4. Naumov A.V. Rossiyskoe ugolovnoe pravo.-M:. BEK. 1996. p. 151.

5. Criminal Code of the Republic of Uzbekistan. https://lex.uz/docs/111453
6. Jevlakov E.N. "Ecological violence and ecological crimes". // "Beliye alvi", M:.1996, p.22.

7. Jevlakov E.N. Ecological difficulties: concepts, types, problems of responsibility. Abstract of the PhD dissertation of Law. // M:.1991. p.23.

8. Jevlakov E.N. "Ecological violence and ecological crimes". // "Beliye alvi", M:.1996, p.21

9. Dubovik O.L. Ecological crimes: comments on Chapter 26 UK RF. // "Spark", M:.1998, p.86.

10. Protection and optimization of the environment. K:. Libid. 1990. p.89.

11. The law of the Republic of Uzbekistan "On Waste". 05.04. 2000. p.173, issue \#1.

12. Kudryavtsev V. N. "General theory of crime qualification".

// "Yurist", M:.2001, p.138. 